\title{
Universiteit
}

Leiden

The Netherlands

\section{The Function of Religious Polemics: The Case of the Revelation of John versus the Imperial Cult} Jonge, H.J. de

\section{Citation}

Jonge, H. J. de. (2004). The Function of Religious Polemics: The Case of the Revelation of John versus the Imperial Cult. Retrieved from https://hdl.handle.net/1887/952

Version: $\quad$ Not Applicable (or Unknown)

License: $\quad$ Leiden University Non-exclusive license

Downloaded from: https://hdl.handle.net/1887/952

Note: To cite this publication please use the final published version (if applicable). 


\title{
The Function of Religious Polemics: The Case of the Revelation of John versus the Imperial Cult
}

\author{
H. J. de Jonge (Leiden University)
}

The book of Revelation was written in the Roman province of Asia. As to its place of origin, Ephesus may be considered a good candidate, on account of the fact that the Church in Ephesus is the first congregation which is mentioned in the list of seven Churches to which the work is addressed (1:11 and 2:1). ${ }^{1}$ The book repeatedly argues against the religious veneration of the emperor. ${ }^{2}$ In this contribution I will attempt to establish what the function is of this polemic against the imperial cult in Revelation. ${ }^{3}$

First of all, it is important to observe that it is not so remarkable that Revelation makes the worship of the emperor the object of its criticism. There are at least five reasons why it would be quite natural for Revelation to express the aversion of the writer to the imperial cult. First, the book was most probably written during the reign of Trajan

"The author only says that he "saw" his revelation on Patmos He does not say that he wrote his work from there Even the announcement that the author expencnced his rapture on Patmos (1:9) can best be understood as a plece of literary fiction which is characteristic of this type of wniting in the apocalyptic genre. The narrative framework of apocalyptic literature is always fiction. And one does not need to experience a rapture in order to write apocalyptically; one only needs to be familiar with the apocalyptic literary tradition. The narrative framework of Revelation made the selection of the ssland of Patmos, probably because banishment to an sland (relegatı in insulam) was a well-known Roman punishment (see, e g., Digest 48.22.7.2) and Patmos was situated not too far (fifty miles) from Ephesus

${ }^{2} \operatorname{Rev} 13: 4,8 ; 13: 11-18 ; 14: 9-11 ; 15: 2,16 \cdot 2,13 ; 19: 20,20: 10$ It 15 possible that there are many other allusions to the imperial cult in Revelation, but other allusions are not so easily ascertained

${ }^{3}$ Revelation also carnes on another polemic; namely, a polemic with the Jews of the region On this polemic, see, $\mathrm{c} g, P$. Borgen, "Polemic in the Book of Revelation" in Early Chrstianty and Hellenistic Judatsm (ed. P. Borgen; Edınburgh: T\&T Clark, 1996), 275-91. 
(98-117 CE). ${ }^{4}$ It is from this time period-approximately $112 \mathrm{CE}$, to be more precise-that we have the first literary witnesses to report that Christrans in Asia Minor fell into difficulties because of their refusal to pay religious homage to the emperor. ${ }^{5}$ Second, durng the first half of the second century, the impernal cult enjoyed its greatest affluence in Asia Minor, greater than during any other period between $50 \mathrm{CE}$ and $250 \mathrm{CE}^{6}$ Third, the imperial cult was the most propagated form of public religion in Asia Minor during the Trajan era. ${ }^{7}$ Fourth, the Churches to which the book of Revelation was written were located in cities in Asia where the impenal cult was especially prominent durnng the reign of Trajan. Not only were there temples and ceremonies for the emperor and his family in Ephesus, Smyrna, Pergamum, ${ }^{8}$ Thyatira,

${ }^{4}$ This datung also receives the preference of the most recent commentator, D Aune, Revelation (WBC 52/1-3; Dallas: Word Books, 1997, 1998), 1.lvin: "durnng the early part of the reign of Trajan." In my view, 17:10 is especially compelling for a date dunng the tume of Trajan. The author presents himself as writıng dunng the reign of an emperor whose successor will reign for only a short time. But how can he know that this successor will only reign for a short time unless his reign has already come to an end? In addition, the author knows that the short reign of this ruler will be followed by the reign of yet another emperor Titus (79-81) and Nerva (96-98) ruled for a remarkably short time. Thus, the author must have wntten durng the reign of Domitian (81-96) or Trajan (98-117). Since there is no evidence of the persecution of Chnstians durng the time of Domitian, Revelation can best be dated to the reign of Trajan The number of the beast, 666, can be interpreted with gematna as referning to Nero, Domitian, Nerva, and Trajan. For example, Trajan's name in Greek, NE.TPAI. $\Sigma$. (Nepous Tpalavòs $\Sigma \varepsilon \beta \alpha \sigma \tau \delta \varsigma \varsigma[\Sigma \varepsilon \beta \alpha \sigma \tau \delta \varsigma \varsigma=$ Augustus] $)$ can be read as $50+5+300+100+1+10+200$ $=666$. As a result, this number offers no clear evidence for establishing a date However, the allusions to a threat from the Parthians in 6.2, 9.14-19, and 16.12-14 are indicative of a date durng the reign of Trajan Cf J. Herzer, "Der erste apokalyptische Reiter und der Konıg der Konıge," NTS 45 (1999) 230-49, sce 234

${ }^{5}$ Pliny, Ep. 10.97 .

${ }^{6}$ S. R. F. Price, Rituals and Power. The Roman Impenal Cult in Asia Minor (Cambridge: Cambridge University Press, 1984), 59.

${ }^{7}$ Price, Rituals and Power, 130; S. Mitchell, Anatola: Land, Men, and Gods in Asta Minor (2 vols., Oxford: Clarendon Press, 1993), 1:113. "No other cults had so widespread a distribution."

${ }^{8}$ Pergamum had two famous temples for the impenal cult. In 29 BCE it was the first city of Asia to receive the authonzation from Octavian to establish a provincial cult and temple for Rome and the emperor. A cult and temple in honour of Trajan were founded in 114 CE, Price, Rituals and Power, 252; S. J. Fnesen, Tunce Neokoros. Ephesus, Asta and the Cult of the Flavian Imperial Family (Religions in the Graeco-Roman World 116; Leiden: Brill, 1993), 58. The phrase "throne of Satan" in Rev 2.13 may refer to the temples for the imperial cult in Pergamum (R. H. Charles, The Revelation of St. John [2 vols.; Edınburgh: T\&T Clark, 1920], 1:60-61), but this cannot be ascertaned The 
Sardis, Philadelphia, and Laodicea, ${ }^{9}$ but Ephesus, Smyrna, Pergamum and Sardis, along with Cyzicus, were also the very cities where the native political organization - the Koinon, a provincial council which was composed of representatives from the cities of Asia-alternatingly held its annual meeting. ${ }^{10}$ The principal task of the Koinon was the organization of the cult of the emperor. The fact that these cities took turns as the residence of the Koinon was undoubtedly an extra menace to the Christians who lived there. Fifth, it was precisely the public character of the imperial cult which made this religion so threatening for Christians. For the Christians it was often very difficult to avoid participating in, or attending, the public celebrations (processions, prayers, singing, recitals, sacrifices, sacrificial meals, games, athletic contests, horse races, gladiator fights, animal fights, etc.) without appearing to be disloyal. In the eyes of their compatriots, the Christians who refused to participate in these celebrations enjoyed the advantage of the peace, the social stability, the benefits, and the prosperity which the imperial government and the emperor's house provided, but they were not willing to pay the homage which was due to the emperor for providing these benefits. For this reason Christians were readily considered to be social parasites, and they were often distrusted and discriminated against on the grounds of antisocial behaviour. Sometimes the indignation of their compatriots got so out of hand that charges were even brought against Christians because of their antisocial behaviour. If they remained unwilling to express their loyalty to the emperor by offering a modest sacrifice to him or for him (hardly any differentiation was ever made as to whether a sacrifice was for the emperor or to him), ${ }^{11}$ then the Roman governor could use his

possibility cannot be ruled out that the founding of the temple in honour of Zeus Philios and Trajan in $114 \mathrm{CE}$ formed the histoncal background of the genesis of Revelation.

${ }^{9}$ Price, Rituals and Power, 250-65. For Thyatıra, see Mitchell, Anatolia, 1:102. For Philadelphia, see Mitchell, Anatolia, 1:100.

${ }^{10}$ W. M. Calder, E. W. Gray and S. Mitchell, "Ası, Roman Province," $O C D^{3}$ 189-90; see 190. Athletic festivals associated with the provincial cults of the emperors, celebrated on a regular basss, and sponsored under the auspices of the Koinon, took place in the cities of Pergamum, Smyrna, Ephesus, Cyzicos, Philadelphra, Laodicea, Sardis, and Tralles (Fnesen, Tunce Neokoros, 114). This resulted in an average of two provincial athletic competitions in Asia every year (ibid., 115), accompanicd by various religious ceremonies.

${ }^{11}$ The sacrifice was in actuality offered in front of a statue or a sculptured bust of the emperor. It normally consisted of the burning of some incense or the libation of some wine. 
powers to do with them whatever he deemed to be necessary for, or in the interest of, public order and authority. ${ }^{12}$

It is true that the Christians' refusal to worship the emperor played only a marginal role in their persecution. Normally it was not the grounds of the charges brought against them, but at most an element in furnishing evidence for their being Christians and their abandonment of the pagan cults in general. ${ }^{13}$ However, in the case of Revelation, passages such as 13.15 and 20.4 demonstrate unmistakably that there was a link between the persecution of Christians and their refusal to worship the emperor. ${ }^{14}$

One should not forget that in the first two decennia of the second century the Christians still represented an extremely small minority, not even one per cent of the population. In the years 110-115, there were probably only approxımately 2 Christians per 1000 people ${ }^{15}$ This means that in a city like Ephesus, which had a population of around 200,000 inhabitants, ${ }^{16}$ there were probably about 400 Christians. ${ }^{17}$ These Christians were probably scattered out over eight to thirteen different congregations. ${ }^{18}$

In addition, one should take into account that the imperial cult enjoyed the warm sympathy of the pagan population. This was not a duty which was imposed upon the people from higher up The wealthy occupants of the cities competed with each other in their generosity to

${ }^{12}$ G E M de Ste Croix, "Why were the Early Chnstians Persecuted?" Past and Present 6 (1963) 1-38, repninted in Studies in Ancient Society (ed M I Finley, London Routledge and Kegan Paul, 1974), 210-49

${ }^{13} \mathrm{~F}$ Millar, "The Impenal Cult and the Persecutions," in Le culte des souverams dans l'empire romain (ed W den Boer, Entretiens de la Fondation Hardt 19, Geneva Fondation Hardt, 1973), 145-65

${ }^{14}$ See L J Lietacrt Peerbolte, The Antecedents of Antichnst A Traditio-histoncal Study of the Earliest Christian Views of Eschatological Opponents (JSJSup 49, Leiden Brill, 1996), 120

${ }^{15} \mathrm{R}$ Stark, The Rise of Christtanty A Sociologist Reconsiders History (Princeton Princeton University Press, 1996), 12-13

${ }^{16}$ Price, Rituals and Power, 28, Stark, Rise, 136-37

${ }^{17}$ The other large cities of Asia were Pergamum (120,000 inhabitants), Sardis (100,000), and Smyrna (75,000), Stark, Rise, 136-37

${ }^{18}$ As long as Chnstians met as house churches, any given congregation could hardly number more than 50 members and would normally have numbered fewer If the number of congregations in Ephesus was about ten, there is no reason to assume that all these congregations shared the author's radical repudiation of Roman government and culture In fact, the author's attitude may well have been rather exceptional Paul, Mark, Luke, and 1 Clement are all much less negative towards the Roman authorties 
be allowed to make financial contributions to the building of temples and the organization of ceremonies and games. The cities also competed with each other to be allowed to inaugurate a new cult for the emperor or for a member of the imperial family. By venerating the emperor and other persons belonging to the imperial house, the cities, which did not play an official role in the political administrative system of the imperial or provincial government, tried to develop an inroad into the supreme centre of power. "Emperor worship was not a political subterfuge, designed to elicit the loyalty of untutored provincials, but was one of the ways in which Romans themselves and provincials alongside them defined their own relationship with a new political phenomenon, an emperor whose powers and charisma were so transcendent that he appeared to them as both man and god."19 Emperor worship was a genuinely religious response to the metaphysics of social order. ${ }^{20} \mathrm{Via}$ the cult of the emperor, the cities ritualized the relationship between themselves and the emperor, whereby they increased their self-respect and their prestige. The city councils as well as the inhabitants of the cities, from the very top to the very bottom, ${ }^{21}$ gladly possessed temples and ceremonies for the imperial cult, including the various contests, games, and spectacles which were affiliated with it.

Let us first examine the kind of critique that the author of Revelation directs against the imperial cult. This will allow us at the same time to see the means that the author uses to wage his polemic.

The polemic begins with the author's explicit and literal demonization of this religion. That which is venerated in the cult of the emperor is according to $13: 11$ nothing less than "the Dragon," that is, the Devil and Satan, the ancient serpent (12:9). ${ }^{22}$ The reason why the object of

${ }^{19}$ Mitchell, Anatolia, 1:103.

${ }^{20}$ A. Brent, The Imperial Cult and the Development of Church Order (VCSup 45; Leiden: Brill, 1999).

${ }^{21}$ Rev 13:16

${ }^{22}$ I do not have the space here to give a detalled interpretation of chapter 13. Let it suffice for me to say that the "beast from the sea" in 13:1-8, which is also called "the first beast" (13:12), stands for the Roman Emprre. However, in v. 8 (auंróv, masculine; and perhaps also in v. 4), it represents the emperor who is religiously venerated. The "beast from the earth" in 13:11, which is also called the "other beast" (13:11), is a representation of the entire system of institutions that organize and maintain the impenal cult; for instance, the Council of the cities of Asta, the Komon, and the priesthoods, provincial as well as municipal, in the imperial cult. In 13:14-18, though, the second beast is once again a cancature of the emperor. The imagery of the beasts in chapter 13 
the imperial cult's veneration is portrayed as the Dragon is, because Rome and the emperor have received their dominion and power, in the view of the author, from the Dragon (13:4). The institutions which are responsible for the imperial cult (for example, the provincial council of the cities of Asia-that is, the Koinon-and the various priesthoods involved in the imperial cult) derive their authority and power from Rome (13:12); in this way, they are indirectly dependent upon the Dragon (Satan). From the vantage point of the author, Rome receives its power from the Dragon (13:2). And if it can be said that imperial Rome is guilty of haughty and blasphemous words against God (13:5), then the same accusation can be brought against the institutions that organize and maintain the imperial cult because they are authorized by Rome (13:12). In the eyes of the author, the imperial cult is one great blasphemy.

The demonization of the imperial cult also arises in chapter 16. In this chapter the institutions that are responsible for the cult of the emperor, which is here depicted as "the false prophet," are portrayed as being possessed with a "foul spirit" (16:13) and the spirit of demons (16:14). The object of the imperial cult, the emperor, is characterized by the author of Revelation as a blasphemous parody of Christ: he perceives the emperor as a beast with two horns "like a lamb" (13:11). The imperial cult is possessed with an evil spirit which is assembling the kings of the whole world for the eschatological battle, the final battle against God and Christ (16:14-16).

The organizers of the imperial cult "deceive the inhabitants of earth" by coercing them to make an image for the emperor $(13: 14)$. In Jewish apocalyptic literature, "deception" is a characteristic of several eschatological opponents of God; in early Christian apocalyptic literature, "deception" becomes a standard characteristic of the great, definitive, eschatological opponent, of God. ${ }^{23}$ In Rev 13:14, the role of the eschatological opponent of God is cast upon the administrators of the imperial cult. This is why they are repeatedly called "the false prophet" $(16: 13 ; 19: 20 ; 20: 10)$. The author says that this false prophet deceives is rather inconsistent and ambiguous.

${ }^{23}$ See e g, 1 Enoch 54:5-6: Azazel's hosts become servants of Satan and lead astray those who dwell on earth; $\mathrm{cf}$. $56: 4$ "the days of their leading astray will no longer be counted"; and 69:28 "those who led astray the world will be destroyed"; 1QS III, 20-24: the Angel of Darkness leads the nghteous ones astray, Stb Or. 3:68-69 (probably Christran): "Bchar misleads pcople; he will also mislead many fathful and chosen Hebrews." Sec also Rev 12:9; 20:10; Mark 13:22; 2 Thess 2:1-12; Did 16.4, ctc 
people (19:20). In this way, the author places the imperial cult on a par with "the Devil and Satan, the deceiver of the whole world" (12:9).

Furthermore, the author of Revelation attempts to disqualify the participants in the imperial cult by persistently uttering the explicit expectation that they will ultimately suffer a horrific and eternal punishment (14:9-11). For that matter, they are already being punished in the present world (16:2). The empire and the imperial cult will finally be definitively thrown into the lake of fire and sulphur $(19: 20 ; 20: 10)$ and will thus be condemned to eternal incineration. Conversely, those who are able to resist the temptation to participate in the imperial cult will finally sing triumphantly the song of Moses (15:2-4).

Another way the author tries to disqualify those who participate in the imperial cult is by categorizing them within the group of people "whose names have not been written from the foundation of the world in the book of life of the Lamb" (13:8; cf. 17:8). ${ }^{24}$ In Jewish and early Christian apocalyptic tradition, this is a conventional way of characterizing opponents as being absolutely dishonourable and completely reprobate. According to the author, those who do not keep their distance from the imperial cult are excluded from God's favour for eternity.

The use of the tradition of the "book of life," however, also has another function. It is used to reassure the readers. They should not be amazed or surprised that some people allow themselves to be seduced into the abominable practices of the veneration of the emperor. After all, these are people who, according to God's plan, were already destined a priori to fall away from him: their names were missing from the "book of life" from the very beginning. It is therefore not necessary for the Christians to become overly alarmed by the misbehaviour of those who worship the emperor. This was already foreseen in God's plan. The behaviour of these people is appalling, but it is not a sign that history has got out of control. The course of history has not been derailed; it has not degenerated into total chaos. History is still progressing according to God's plan. God's plan does not fail. He accomplishes it in conformity to his books, including the "book of life." 25 Thus, the Christians should

\footnotetext{
${ }^{24}$ For the concept of the book of life, see Dan 12:1; Jub. 30:22;36:10; 1 Enoch 47:3; 104:1; 108:3; 1QM 12:2; Joseph and Aseneth 15:4; Rev 3:5; 20:12, 15; 21:27. Cf. Phil 4:3; Luke 10:20; Heb 12:23; 1 Clem. 53:4; Herm. Sim. 2:9; Herm. Vis. 1:3.2.

${ }^{25}$ In addition to the Book of Life, God has a book in which people's deeds are recorded. At the final judgement, people will be judged according to their record in
} 
not allow themselves to become too disturbed by the abomination of the imperial cult.

The author does not present a careful explanation of his objections against the imperial cult. He does not share with the reader exactly what his disapprobations are. The objections which he does in fact mention are objections which are traditionally established. For instance, he objects to the worship of images $(13: 14 ; 14: 11 ; 16: 2)$, or he protests against the deceit by which those responsible for the worship of the emperor lead people astray $(13: 14 ; 19: 20 ; 20: 10)$. Nonetheless, it is clear that the principal objection of the author is that the imperial cult is closely interlaced with the power of Rome (13:12). Indeed, the imperial cult and political administration were two aspects of one reality: the regime of Rome. It is evident that the aversion of the author of Revelation to the imperial cult is closely related to his aversion to the Roman government, whose repressive power was exercised against the Christians $(13: 7 ; 17: 6)$. Belonging to an extremely small minority, the author was antagonistically opposed to the ruling political order, including the religious system of the imperial cult which sanctioned that order. The author felt absolutely unable to identify with the ruling political system. This view need not have been shared by the majority of the Christians of Asia. As we pointed out above, there is a reasonable chance that, in its assessment of Rome, Revelation is not representative of the Christian Churches of Asia in general. ${ }^{26}$ The author's extremely negative view of Rome was probably the exception rather than the rule among contemporary Christians in Asia. "The anti-Roman stance of Revelation was unusual in early Christianity." 27 But this does not prevent Revelation's rejection of Rome from being radical and complete.

I will now attempt to decipher more precisely what the function is of the polemic against the imperial cult in the book of Revelation.

(1) As we have already seen, the author of Revelation stigmatizes the religious veneration of the emperor by pronouncing unambiguously that it is demonic. The imperial cult is not only the work of the Devil (13:4.11-12), it is also in the service of the Devil (13:4.15). This is without a doubt one of the most effective ways that this religion could

both books, but for each individual person the two books will turn out to lead to the same judgement. See Rev 20:12.

${ }^{26}$ See $n .18$ above.

${ }^{27}$ A. Yarbro Collins, "Vilification and Self-Definition in the Book of Revelation," HTR 79 (1986): 308-20. The quotation is from p. 318. 
be condemned. However, it is important to keep in mind that the book of Revelation was not intended for readers outside the Christian community; it was written exclusively for listeners within the Churches of Asia. As can already be seen in the heading, the book as a whole is a revelation addressed to the servants of God, that is the Christians (1:1). Blessings are pronounced at the beginning of the book upon the one who reads the book aloud and upon those who hear it being read (1:3); in other words, a blessing is pronounced upon the one who reads the book aloud at the gathering of the Christian congregation as well as upon those who are present to hear its reading at the gathering. These words compel one to think primarily of the gatherings of the Christian Churches on Sunday evening. ${ }^{28}$ The people first shared a meal together, the Lord's Supper; then they stayed together in order to exchange all kinds of inspiring and encouraging messages, to prophesy, to pray, and to sing. In this gathering after the meal, the opportunity was also given for the reading aloud of letters or messages, for example, the message of "John to the seven Churches that are in Asia" (1:4). ${ }^{29}$ The author calls himself "Your brother and companion in the persecution and the kingdom and the patient endurance in Jesus" (1:9). The book is addressed, then, exclusively to Christians. The writer says explicitly that he received the message from Christ to write and send his book "to the seven Churches, to Ephesus, Smyrna, Pergamum, etc." (1:11).

Thus, the book Revelation is not meant for readers outside the Christian Churches, but for listeners within the Church. The establishment of this fact has a direct effect upon our determination of the function of the book as a whole as well as the function of the assault which the book wages against the imperial cult. It is impossible that the function of the polemic of the book should be to dissuade people from outside the Church from participating in the imperial cult; this intention would not be possible because of the fact that the book is simply not addressed to outsiders. The function of the critique against the imperial

${ }^{28}$ Pliny, Ep 10:97: "Affirmabant . . . stato dic . . . morem sibı . . . fuisse coeund 1 ad capiendum cibum, promiscuum tamen et innoxium." Cf. Acts 20:7, 11; Did. 14; Heb 10:25. In 1 Cor 11:17-14:40, a simular gatherng is described: a supper followed by a meeting consisting of speeches, prophecies, and other oral contributions from the participants. For the shape of the weekly gathering of the early Christian communitics, see M. Klinghardt, Gemeinschaftsmahl und Mahlgemeinschaft: Soziologie und Liturgie fruhchrstlicher Mahlfeiern (Texte und Arbeiten zum neutestamentlichen Zeitalter 13; Tübıngen: Francke, 1996), esp. 269-371.

${ }^{29}$ Cf. 1 Thess 5:27; Col 4:16 
cult must lie in the writer's endeavour to substantiate the rightness of the group to which the author, the reader, and the listeners belong. In other words, the function of the polemic is to confirm and strengthen the religious identity of the author and the Christian groups that are being addressed. The listeners are given the assurance: the outsiders are completely off the track and wrong; you and I are right.

This somewhat general conclusion that the critique against the imperial cult is intended to consolidate the religious identity of the author and the groups to which he is writing can be refined to some extent. We will attempt to elaborate on this refinement in the following paragraphs $2-7$.

(2) The author characterizes those who are responsible for the imperial cult as seducers, and he describes the entire system of emperor worship as the "false prophet" $(13: 14 ; 16: 13 ; 19: 20 ; 20: 10)$. In doing this, he announces explicitly that the officials of the imperial cult are deceivers who want to propel the people into accepting objectionable ideas and practices. But the author does not intend for reproach to reach the officials. More importantly, his disparagement implicitly claims the rightness of his own group and warns his listeners to be on their guard against the temptation which emanates from the imperial cult. Thus, the function of the polemic here seems to be to stimulate the listeners to vigilance.

(3) One of the specific means that the author of Revelation uses to predicate the absolute wrongness of those who support the imperial cult is his prognosis concerning their future destiny. They will still be punished in this world (16:2), and they will ultimately be definitively condemned and thrown into the lake of fire for eternity (14:9-11; 19:20; 20:10). Those who resist from participating in the imperial cult will triumph as conquerors (15:2-4). With this portrayal of the future fate of those who worship the emperor on the one hand, and those who reject the imperial cult on the other hand, the hearers of the book are not only encouraged to persist in their renunciation of the imperial cult (cf. paragraph 2 above), but they are also consoled and comforted if their present position has caused them to become victims of discrimination, oppression, and persecution. Hence, there is also a moment of consolation built into the polemic for those to whom the letter is directly addressed.

(4) When the author postulates that the names of those who participate in emperor worship have never, even from the beginnings of the world, 
been written in "the book of life" (13:8), he employs an effective means of radically proclaiming that his opponents are in the wrong. For those whose names are not listed in this book, there is no salvation at the last judgement (20:15). They are eternally excluded, as they always have been, from God's plan for the salvation of his people. The author characterizes those who are involved in the imperial cult as being completely shut out from God's favour. Those who listen to these words of the book of Revelation are expected to draw the conclusion that they should completely distance themselves from the imperial cult. The severe disqualification of the opponents carries implicit instructions for the listeners as to how they should behave. Once again, then, the function of the polemic here is parenetic or ethical (cf. paragraph 2 above).

(5) Another function of the author's assertion that the names of those who worship the emperor are not listed "in the book of life" is the reassurance of his readers. The Christians to whom the book is addressed can be reassured that the misbehaviour of those who venerate Rome and the emperor is not some new phenomenon which was not foreseen in God's plans. These people had always been excluded from God's plan for the salvation of his people. And so their misconduct is not really unexpected. God has not lost his control of history. History is still unfolding according to God's eternal plan. Thus, those to whom the book is addressed can be reassured.

(6) In 13:8 the author refers to the widespread propagation and popularity of the imperial cult with the words "All on earth will worship it [i.e., the beast representing the emperor]." Then he goes on to say in 13:10: "Here the fortitude and faithfulness of God's people have their place." ${ }^{30} \mathrm{He}$ repeats these words in 14:12: "Here the fortitude of God's people has its place-in keeping God's commands and remaining loyal to Jesus." The latter exhortation follows immediately upon the author's warning that "there will be no respite day or night for those who worship the beast and its image" (14:11). The passages quoted from 13:10 and $14: 12$ show that the function of the author's polemic against the imperial cult is also to exhort the hearers to remain firm in their refusal to associate with the cult of the emperor. One function of the polemic against the imperial cult, therefore, is the admonition to the hearers to persevere in their refusal to participate in the cult.

${ }^{30}$ New English Bible. 
(7) The question can be asked about whether the polemic against the imperial cult in Revelation was not also intended to exhort the readers not to lapse into the laxity of fellow Christians who did not see any harm in participating in the impenal cult, or at least in vanous aspects of it. The temptation was certainly very great for some Christians to attend the processions, sacrifices, games, races, and fights of the gladiators and wild animals. Some of them may have taken even a further step and participated in the eatıng of the meat that had been offered as a sacrifice in the imperial cult. In order to participate in this ritual, some of them may possibly have burned incense in a bowl in front of an image of the emperor, or perhaps they had offered a libation of wine to the emperor. In any case, it was not uncommon for Christians in the cities of Spain around $300 \mathrm{CE}$ to fill the honorary office of priest (flamen) in the imperial cult, both at the provincial level and the municipal level. ${ }^{31}$ This was possible because the main responsibilities associated with this honorary office were to preside over the games and to underwrite their costs. Priests who were Christians and who did not want to offer the sacrifices themselves could have the sacnfices offered vicariously through non-Christian colleagues. But some of the Christian flamines also offered sacnfices themselves. The Council of Elvira (ca $306 \mathrm{CE}$ ) found it necessary to promulgate several disciplinary measures against various forms of active participation by Christian flamines in the cult of the emperor. But the Council did not, and could not, ${ }^{32}$ forbid Christians to occupy the priestly office in the imperial cult itself. The measure and degree to which Christians participated in the rituals of the imperial cult will have varied. But Christians could certanly participate, and contınue to participate, in the cult.

In the letters to the various congregations in chapters $2-3$, Revelation gives a distinct warning against the inappropriate behaviour and laxity

${ }^{31}$ L Duchesne, "Le Concle d'Elvire et les flammes chrétiens," in Mélanges Renter Recuell de travaux publiés par l'École pratique des hautes études (section des sciences histonques et philologiques) en mémoire de son préstdent Léon Renter (BEHE 73, Parns Vieweg, 1887), $159-74$

${ }^{32}$ The priestly office in the imperial cult was an extremely prestigious and socially important position Well-to-do people who could afford to underwrite the huge costs of the office would normally aspire to the post If such wealthy and prominent persons who wanted to assume the office of priest in the impenal cult were Chnstians, the Church was not in a position to forbid them to accept the office On the contrary, the Church had every interest in trying to keep these leading figures and benefactors within their community 
of Christians $(2 \cdot 2,14-15,20-23 ; 3: 1)$. Some of the Christians were undoubtedly less rigorous in the Christian lifestyle than the author thought was proper. In Pergamum, some of the Christians were participating in banquets where food was eaten which had been sacrificed to 1dols (2:14). The same thing was happening in Thyatıra (2.20-23) It is certainly possible that the author is protesting here against the participation of Christians in sacrificial banquets which were part of the imperial cult. But this conclusion cannot be made with any certainty. ${ }^{33}$ It is also possible that these sacrificial banquets were held in worship services to deities other than that of Rome, the emperor, or the imperial family. As far as the inquiry of this paper is concerned, this means that the question concerning the function of the criticism of the misconduct of Christians in Pergamum and Thyatira must remain undecided It is not possible to ascertain whether this criticism in fact was intended to exhort the readers not to lapse into participation in the imperial cult

According to a recent interpreter of Revelation, the vehement attack that the book directs in general against Rome as a political and religious reality is meant to warn the readers not to follow the path of other Christians who have succumbed to the temptation to participate to some extent in the impenal cult. ${ }^{34}$ If this interpretation is correct, then at least a part of the function of the polemic aganst the cult of the emperor $1 \mathrm{~s}$ to warn the readers against Christrans who are less scrupulous. However, one cannot determine with certainty whether Revelation ever focuses its attention specifically on Christians who participate in some measure in the veneration of the emperor. Thus, it remains doubtful whether one of the functions of the polemic against the imperial cult is to warn the readers against the behaviour of less scrupulous Christians.

\footnotetext{
${ }^{33}$ Aune, Revelation, $1 \mathrm{lxv}$ "Rev 2-3, then, does not reflect a persecution of Christians sponsored by Rome or Roman authonties, nor does it contain any allusions to the imperal cult ( ) Klauck's attempt to find evidence of the imperial cult in the proclamation to Pergamum in Rev 2 12-17 is hardly convincing "Aune is referring to H -J Klauck, "Das Sendschreiben nach Pergamon und der Kasserkult in der Johannesoffenbarung," Biblica 73 (1992) 153-82

${ }^{34} \mathrm{~L}$ L Thompson, The Book of Revelation Apocalypse and Empire (Oxford Oxford University Press, 1990) For a succinct but accurate critique of Thompson's position, sec Lietaert Peerbolte, Antecedents of Anuchrist, 119-21
} 


\section{Conclusion}

In order to evaluate and determine the function of the polemic that is waged in Revelation against the imperial cult, one has to keep several historical circumstances always in mind. First, the imperial cult was extremely popular; it was undoubtedly the most popular form of religion in Asia at the time Revelation was written. Proof of this fact is provided by an abundance of epigraphic and numismatic evidence. The popularity of the cult is even recognized by the author himself. He writes, "The whole world went after the beast in wondering admiration" (13:3). "All on earth will worship it" (13:8). Those who worship the second beast are "the earth and its inhabitants" (13:11), "everyone, great and small, rich and poor, slave and free" (13:16). Second, socio-historical research has demonstrated that, although the Christian movement was growing rapidly, the author still belonged to an extremely small minority, approximately 0.2 per cent, of the population. Third, Christians who chose not to participate in the imperial cult suffered an economic boycott (13:17) ${ }^{35}$ Fourth, some of these Christians were killed (13:15; 20:4).

These circumstances made it impossible for the author to identify with the political order. He rejected both the Roman regime and its religious counterpart, the worship of Rome and the emperors, and chose to depict these as institutions brought about and inspired by Satan. However, his polemic against the imperial cult is not directed against non-Christian people who are involved in the cult. Rather, the author directs his remarks exclusively to Christians.

As a result, the function of the polemic of Revelation is

1. to affirm and strengthen the religious identity of the group to which the Christians to whom he has addressed the book and the author himself belong. Stated more precisely, the function of the polemic is

2. to summon the readers to vigilance against the strong attraction and temptation of the imperial cult,

3. to offer consolation in the readers' situation of discrimination and oppression,

${ }^{35}$ On this aspect of the Christians' situation un Asia, see J. N. Kraybill, Impenal Cult and Commerce in John's Apocalypse (JSNTSup 132; Sheffield: Sheffield Academuc Press, 1996). 
4. to strengthen the readers in the conviction that they have made the right choice in refraining from participating in the imperial cult,

5. to urge them to persevere in this decision, and

6. not to allow themselves to become overly alarmed by the fact that so many people participate in the imperial cult: the large number of participants does not mean that God's plans are failing.

Whether the author intends to warn the readers more specifically so that they will not lapse into the latitudinarianism and the laxity of other Christians who did in fact participate in the imperial cult-for instance, by partaking in the festivities or the sacrificial meals associated with the cult, or by eating meat that had been sacrificed in the imperial cultcannot be ascertained. 